\title{
3
}

\section{The Croatian historical statehood narrative}

In his 1998 state of the nation address, the Croatian President Franjo Tuðman noted that with the restoration of the Croatian Danube region including Vukovar 'to our homeland', '[t]he centuries-old dream of the Croatian people has thereby been completely fulfilled'. 'Similarly, the new constitution promulgated shortly after independence proclaimed 'the millennial national identity of the Croatian nation and the continuity of its statehood, confirmed by the course of its entire historical experience in various statal forms and by the perpetuation and growth of the idea of one's own state, based on the Croatian nation's historical right to full sovereignty'.

This chapter explores these abstract claims to historical identity. At the most abstract level, Croatian national identity in the 1990s was constituted by perceptions of a common history and in particular a shared state that can claim ancient roots. Ivo Banac, for instance, noted that 'Croat national apologetics were lopsidedly historicist. The Croats never felt safe enough with strictly national - linguistic and cultural - arguments in favor of their autonomy and statehood.' ${ }^{3}$ This chapter will focus on historical claims to self-rule and the ways that Croatian historians and historical narratives have tended to focus on questions of elite politics and sovereignty rather than the ethnic and linguistic claims expected by primordialists and articulated by sections of the contemporary Croatian nationalist movement. ${ }^{4} \mathrm{I}$ am not arguing that contemporary Croatian national identity is primarily constituted by reference to claims to historical statehood. As I pointed out in the previous chapter, the three levels of analysis are mutually constitutive, with none more important than the others. Neither is this chapter an attempt to chart processes of national integration in other historical epochs in a way akin to Mirjana Gross' study of the socioeconomic foundations of integration in 1850s Civil Croatia. ${ }^{5}$ Instead, it demonstrates that abstract accounts of national identity draw upon a common stock of narrative about historical statehood. These accounts provide the 
'frames' of reference used by competing politicians, intellectuals and others in the 1990s to legitimise particular political programmes. Such frames combine the real and the representational. On the one hand, representations that are wildly at odds with established knowledge tend to be disregarded. The historical statehood narrative could not be sustained and would not be resonant were it a complete fiction. On the other hand, knowledge about what is real is mediated through representation.

\section{The search for ethnic origins}

Although from time to time Croatian nationalists have attempted to articulate an ethnic account of national identity, these have tended to flounder on the impossibility of locating ethnic antecedents. ${ }^{6}$ The one thing that all historians agree on is that the Croats were not the earliest inhabitants of the lands that make up present day Croatia. Key questions for those interested in articulating an ancient ethnic origin for Croatian national identity therefore include whether or not the Croats were Slavs and, if so, how closely they were related to other Slavic groups. Also, such writers need to address how the Croats came to occupy the Roman lands of Pannonia and Dalmatia.

Ivo Banac's understanding of the migration of Slavs into the region is that they came to the Balkans as permanent largely agrarian settlers whose advent can be divided into several stages. In the first decades of the sixth century they aided numerous invaders such as the Avars and Huns in attacks over the borders of the Byzantine Empire. Unlike some other writers, Banac does not believe that these Slavs were sub-divided into pre-national groupings such as Slovenes, Serbs and Croats.

Other writers, however, contend that it is possible to distinguish the Croats from other Slavic groups and, as we shall see later, this is vital to accounts that attempt to trace Croatian national identity back to a prior ethnic group. Marcus Tanner used texts ascribed to Emperor Heraclius to suggest that the Croats began inhabiting the provinces of Pannonia and Dalmatia after the sack of Split by the Avars in AD 614. According to Tanner, the Emperor claimed that the Croats were distinguished by being Aryans and heretics until their incorporation into mainstream Christianity in the middle of the seventh century. ${ }^{8}$ Stephen Gazi supported the view that the Croats were a distinguishable group who settled in Pannonia and Dalmatia around the sixth and seventh centuries. ${ }^{9}$

The most popular explanation is that the Slavs were a diverse and disunited group and that there were indeed recognisable differences between different Slavic groups. According to Emperley, the Slavic tribes were scattered and numerous and recognised no external authority. Furthermore, the Slavs were 'split up into several distinct groups which are approximately those of today'. ${ }^{10}$ This view was supported by Roger Portal who argued that ' $[t]$ here is at the present time no specifically Slav civilization, common to all the Slavs ... and in 
all probability there never has been'. ${ }^{11}$ Furthermore, Portal insisted that other than sharing linguistic characteristics the Slavs exhibited more differences than similarities. ${ }^{12}$ The view that the Slavs migrated from one particular area is also dismissed, as George Hoffman suggested that Slavic tribes descended on the Balkans from every conceivable direction, adding to the difficulty of speaking of the Slavs as a common ethnie. What can be determined is that it was in this milieu of migration and conflict that a group (or groups) that came to be known as 'Croats' settled in the territories that make up present day Croatia.

One of the most basic statements concerning the Croats is that they are ethnically Slav, though as we have seen it is probably problematic to consider the Slavs as an ethnie. Simon Vladovich contended that most sources agree that the Croats were a Slavic group of tribes who lived northeast of the Carpathian Mountains between the Dnieper and Dniester rivers. ${ }^{13}$ They then journeyed to north-central Europe where they created the state of White Croatia before migrating southwards in the seventh century ${ }^{14}$ However, there are some discrepancies with this account. Stanko Guldescu pointed out that in the Book of Annals, written by Alfred the Great of England (871-901), there is mention of a state known as White Croatia with its seat in the Polish city of Krakow - some 150 years after the Croats were supposed to have taken Pannonia and Dalmatia. ${ }^{15}$

Roger Portal agreed that the Slavs probably originated from the Carpathian region but did not give any credence to the idea that separate groups took different routes to the Balkans. ${ }^{16}$ However, Ferdinand Schevill offered an entirely different geographical starting point for the Slavs - the marshes of Ukraine. ${ }^{17}$ Given these disagreements, we cannot simply accept that the Croats were either an indistinguishable Slavic group intermingled with the rest or (if we accept Vladovich's account) an identifiable group that took an alternative route to the Balkans. Furthermore, several ethnic nationalist historians have questioned whether the Croats were Slavs at all.

There are several historical anomalies that support the view that the Croats were not a Slavic group. For example, some writers argued that the name 'Croat' suggested an Iranian origin. ${ }^{18}$ The claim that Croats originally resided in Iranian lands is based on an interpretation of what the word 'Croat' means. According to Constantine Porphrygenitus, the Croats were simply 'the people with many lands', while Jan Safaryk argued that the idea of Carpathian roots is substantiated in the name. ${ }^{19}$ Some Croatian scholars opted for this theory, arguing that Greek accounts of a community called Horvatos or Horoatos, which occupied a region of Iran, reveal the first evidence of the existence of the Croats. ${ }^{20}$ The Russian historians, Pogodin and Miler, who discovered Iranian inscriptions bearing the name Horuatus, also supported this view. ${ }^{21}$ However, there is a major problem with this theory. The reason for the Slavic migration appears to have been the search for better land and an escape from the Carpathian mountains and marshes. ${ }^{22}$ To locate the Croats in fertile Iran, therefore, makes their migration inexplicable.

After the Napoleonic Wars, several Croatian intellectuals conceived the 
idea that the Croats were in fact descendants of Illyrians, the first known inhabitants of the Balkan Adriatic coast..$^{23}$ This account can be easily dismissed. Although it is not fully known what became of the Illyrians, there is substantial evidence that they were expelled by the Avars and Croats. Other theories describe the Croats as an Aryan Gothic group, Samartian, ${ }^{24}$ and Ukrainian. ${ }^{25}$ There is archaeological evidence that seems to support a non-Slavic theory of Croatian ethnicity. Most notably, helmets were found in the eighth-century graves of Croats, while it is generally thought that the early Slavs did not wear helmets. ${ }^{26}$

This brief survey indicates that it has proven impossible to point to an ethnic predecessor to Croatian nationhood, even though many writers have tried to do so. It is difficult to tell who the Croats were prior to the first Croatian kingdom. This suggests that rather than being a single ethnic group they were a collection of tribes, a mixture made all the more confusing by their interaction with the earliest inhabitants of Pannonia and Dalmatia. It is only with the advent of a Croatian state that it is possible to speak about Croats with any clarity. As such, it is difficult to make the case for the existence of an ancient ethnic antecedent to Croatian national identity because such an antecedent is impossible to find and is not acknowledged by all but the most extreme of Croatian nationalist intellectuals. This could begin to explain why it is that Croatian claims to national sovereignty in the 1990s were made by reference to a discourse of historical statehood rather than in the ethnic terms that Serbs used to justify their rule over Kosovo. ${ }^{27}$ The Croatian narrative of historical statehood, the abstract story of national identity, is therefore primarily concerned with constitutional arrangements and political programmes.

\section{The Croatian claim to statehood}

The narrative of the historic claim to statehood begins at the start of the 'centuries-old dream' in the form of the medieval Croatian state. The Croatian constitution recalls 'the formation of Croatian principalities in the seventh century', 'the independent medieval state of Croatia founded in the ninth century' and 'the Kingdom of Croats established in the tenth century' ${ }^{28}$ It is on the basis of the medieval state that the Croats make their historic claim to national sovereignty, tracing a continual line of political independence from the time of King Tomislav to the formation of the Kingdom of Serbs, Croats and Slovenes in 1918. The central debates in Croatia's national historiography are not ones of ethnicity or religion, but ones of national governance and sovereignty. Such debates include the exact nature of the coming together of the Hungarian-Croatian union in 1102, the status of Croatia within that union, and the question of whether the Croatian parliament (Sabor) agreed to Croatia joining the South Slav state that was formed at the end of the First World War.

According to most, if not all, Balkan historians, Croatia became a unified kingdom in 924 when Tomislav assumed the title of King of Croatia and 
Dalmatia. ${ }^{29}$ The coronation was recognised by the Pope and thus Croatia began a period of just under 200 years of rule by Croatian kings. ${ }^{30}$ The geographical extent of Tomislav's Croatian state is not fully known and is widely disputed. Tanner suggested that it comprised most of modern Croatia, Bosnia and Hercegovina, and the coastline of modern Montenegro. ${ }^{31}$ Roger Lampe, however, argued that the Croatian state did not penetrate as far south as Dubrovnik, let alone Montenegro, and that Istria was also not included in this state. This view is supported by many Croatian scholars, who argue that the medieval Croatian state extended to the whole region south of the Drava River to the Drina and Neretva Rivers (north of Dubrovnik). ${ }^{32}$ However, the Byzantine chronicler, Porphyrogenitus argued that the Croatian state extended to the entire coastline from Istria to the River Cetina (in Montenegro - south of Dubrovnik). ${ }^{33}$ Importantly, though, most agree that Tomislav was able to unite Pannonian (northern) Croatia with coastal Dalmatia, a union that formed a major part of the so-called national dream of the Croats. ${ }^{34}$

Many of the symbols used by the contemporary Croatian state trace their heritage back to the medieval kingdom. The chequerboard coat of arms, the Sahovnica, is widely thought to have been created in the tenth century by one of Tomislav's predecessors, Stjepan Držislav. ${ }^{35}$ Similarly, the Kuna was developed as a form of currency during this period, its first known use being on the Island of Cres. ${ }^{36}$ The Kuna reappeared as the currency in the 1990s when the Yugoslav Dinar was abandoned. ${ }^{37}$

Along with Tomislav, one of the most significant ancient Croatian kings was Krešimir Petar (1058-74). Krešimir reportedly consolidated the kingdom by unifying the lands into a single kingdom, calling it the Triune Kingdom (CroatiaSlavonia-Dalmatia). ${ }^{38}$ Krešimir's death left the throne vacant, leading to many years of plot and counter-plot among the nobles. Eventually, in 1102, the nobles decided that Croatia should enter into a personal union with Hungary whereby the Hungarian king would be crowned separately as the King of Croatia.

The narrative therefore tells us that Croatia's brief period of statehood came to an end amidst the intrigues of the nobles. The events surrounding the union of Croatia and Hungary are the source of a major historical controversy. Its importance derives from the fact that the historical statehood narrative depends upon the establishment of a continuous line of statehood. Intellectuals and politicians have not tended to concern themselves with the identity of the people who were ruled by the Croatian nobles, only with asserting that there was a continuous line of statehood. According to Croatian historians, then, the nobles gave the throne to Hungary but never lost their independence or sovereignty. Magyar historians, however, claim that Hungary conquered Croatia. The significance of the debate lies in the Croatian claim to an unbroken heritage of historical statehood, which is clearly compromised by the Magyar claim. Perceptions about the exact nature of the union are therefore vital to establishing an abstract idea of Croatian national identity that is based on a continuous line of statehood. 
It is argued that in 1102 the Croatian nobles signed an agreement - the Pacta Conventa - with Koloman, King of Hungary. This agreement confirmed the legitimacy of Koloman's succession to the Croatian throne in return for which Koloman agreed to respect the laws and customs of Croatia. ${ }^{39}$ The exact nature of the agreement, and even its existence, is impossible to determine as historians believe that a transcript of the Pacta Conventa preserved in the city of Trogir is actually a fourteenth-century fake. ${ }^{40}$ There are two competing accounts of the nature of the union, one emerging predominantly from Croat historians and the other from Magyar and Serbian historians. The Croats argue that the union was a personal one in the form of a shared king, while the Magyars and Serbs insist that Croatia was conquered.

The Croatian position was recorded by Despalatović in her work on the nineteenth-century Illyrianist nationalist Ljudevit Gaj. Gaj insisted, 'let it be known to Your Majesty that no ruler has ever subjugated Croatia by force. Rather, after the death of our last king, Zvonimir, we of our free will attached ourselves to the crown of the Hungarian kingdom, as we at this time join ourselves to Your Majesty. ${ }^{31}$ The claim made by Croatian historians is that a continual line of independent statehood can still be traced through the period of the union with Hungary because it was a voluntary union freely entered into by the Croatian nobles. This view of events has a wide circle of support. Ivo Banac contended that, with the death of the last Croatian king, the crown simply passed into royal Hungarian hands as the nearest blood relation to the Croatian Trpimir dynasty. ${ }^{42}$ The existence of such an agreement, and the accuracy of these Croatian claims, is partially supported by evidence of early practices in the 'union'. First, during the first two centuries of the union there were separate crowning ceremonies, one ceremony for the crowning of the King of Hungary and one for the crowning of the King of Croatia. ${ }^{43}$ Second, there is evidence that the Croats continued to make their own laws in their own parliament (Sabor), under their own leaders (Bans), who convened the Sabors and promulgated laws without the King's sanction. ${ }^{44}$ Third, compared to the other 'conquerors' of Croatian lands (principally the Venetians and Ottomans) there are hardly any archaeological reminders of Croatia's union with Hungary, suggesting that the Magyars did not forcibly impose themselves on the Croats. ${ }^{45}$ Finally, prior to 1526 the dukes and Bans of Croatia produced their own currency in Zagreb. These items of currency were engraved with the Croatian coat of arms and the symbols of Croatia and Dalmatia that form part of the present day Croatian flag. ${ }^{46}$

There is, however, an alternative account of events leading up the union of 1102. Whereas many Croatian historians and politicians are determined to trace an unbroken line of sovereign statehood, several Magyar and Serbian historians have been equally determined to undermine these claims. According to Branimir Janković, the Magyars 'swept' into Pannonian Croatia. ${ }^{47} \mathrm{He}$ insists that '[a]fter armed resistance, the Croatian nobility had to yield to superior Hungarian might'. ${ }^{48}$ According to this view, Koloman seized Croatia by force of 
arms, discrediting Croatian claims to continual statehood. ${ }^{49}$ However, there are a couple of points that need to be made about this thesis. Firstly, Magyar claims were not made until the middle of the nineteenth century and formed part of the Hungarian national reawakening under Kossuth (of course, much the same argument could also be levelled about the idea of a personal union first articulated in the fourteenth century). ${ }^{50}$ Second:

[T] he idea that Koloman and his Magyars conquered Croatia by force rests upon the supposition that there was a counter king whom he had to overthrow to accomplish his ends. There is no real evidence that there was any organized opposition at all to his invasions, if it can be called that of the Croatian lands. It should be remembered that there probably was no fixed border between Hungary and Croatia in the eleventh century ... when the House of Trpimir disappeared ... the frontier disappeared too. ${ }^{51}$

It is not the exact nature of the relationship between Croatia and Hungary from 1102 that is of interest to us here but the importance attached to defending the idea of a personal union that is central. The historical statehood narrative insists that it is possible to trace a long history of parliamentary declarations reasserting the Croatian view of events in 1102. For instance, in the early eighteenth century the Sabor declared that 'Croatia as a kingdom was joined with Hungary, but without establishing common citizenship. We were not compelled by force to join Hungary. We accepted only her king and not the kingdom ... we are free citizens and subjects to no one. ${ }^{52}$

This view of history is enshrined in the contemporary Croatian constitution, which asserts the 'preservation of the subjectivity of the Croatian state in the Croatian-Hungarian personal union'. ${ }^{33}$ The union of 1102 therefore represents Croatia's second claim in the historical statehood thesis: the medieval state of Croatia was not demolished but was retained under a personal union between Hungary and Croatia. The actual nature of the relationship is probably most accurately described as being inexplicable in modern terms because it varied from time to time. Sometimes Croatia acted as an independent agent and at other times as a vassal of Hungary. However, throughout this period, 'she [Croatia] retained a large degree of internal independence'. ${ }^{54}$

The next 'signpost' of the Croatian historical statehood narrative is 1526 and the defeat of Hungary by the Ottoman Turks, which prompted Croatia's entry into the Habsburg Empire. Again, the Croatian historical narrative insists that the decision to join the Habsburg Empire was the result of a free choice made by the Sabor. On 29 August 1526, the Ottoman Turks defeated the Hungarian army at the battle of Mohacs. ${ }^{55}$ The battle was particularly devastating for the Hungarians because the last male of the ruling family, Louis Jagellon, was killed, leaving the thrones of Hungary and Croatia without an heir. ${ }^{56}$ According to the Croatian narrative of historical statehood, the Sabor decided to remedy the problem by electing the Habsburg king, Ferdinand, to the Croatian throne. Thus, according to many Croat historians, 'the nobility, entirely of their own 
accord and free from foreign influence, elected Ferdinand ... King of Croatia'. ${ }^{57}$ The Sabor took the opportunity to reassert its autonomy from Hungary by reaffirming the events of 1102. It reputedly declared that, 'after the death of Zvonimir, our last king of fond memory, we joined the holy crown of Hungary by our own free will, just as we do now, the rule of Your Majesty' ${ }^{58}$ Croatian historians also argue that the struggle for ascendancy to the Habsburg throne at this time provides evidence of Croatia's political autonomy. Guldescu, for instance, argued that evidence suggesting that Ferdinand's rival, Zapolya, had to abandon his claim to the throne of Croatia-Slavonia demonstrates Croatia's separate political identity. ${ }^{59}$ Other historians suggest that the Sabor attached conditions to the offer of the crown, such as maintenance of Croatian autonomy and assistance in the defence against Ottoman attack..$^{60}$ Unlike Magyar historians, the Austrians never claimed that they conquered Croatia by force and there appears to be little reason to doubt Croatian claims about the events of 1526 .

The incorporation of Croatian lands into the Habsburg Empire further complicates attempts to trace a continual history of Croatian statehood, because the Sabor became enmeshed in a political framework with two other powers: Austria and Hungary. One of the central debates within Croatian national politics up to the formation of the Kingdom of Serbs, Croats and Slovenes in 1918 was the question of whether to align with Vienna or Budapest. ${ }^{61}$ As a result, the lands of the medieval kingdom became even more divided in this period. Slavonia was separated from Croatia proper, while what was left of Croatia was separated into the military frontier (Vojna Krajina), which was administered directly by the Emperor, and Civil Croatia, administered by the Sabor. ${ }^{62}$ The lands comprising present-day Croatia were divided into five entities. Three of them (Civil Croatia, Slavonia and Vojna Krajina) fell under the rule of the Habsburgs, and the other two (Dalmatia and Istria) were ruled by the Venetians. ${ }^{63}$ It is important to note that northern Croatia and Dalmatia were ruled separately throughout this period and remained so until the formation of the Kingdom of Serbs, Croats and Slovenes after the First World War. This creates further problems for the narrative of historical statehood because after the dissolution (voluntary or otherwise) of the medieval kingdom as many people identified as Croats by their inhabitance of the medieval kingdom lived outside Habsburg Croatia as within it. By the time Dalmatia came under Habsburg rule after the fall of Napoleon the empire was split into the dual Austro-Hungarian monarchy, with Vienna ruling Dalmatia and Budapest ruling Slavonia and Croatia proper. From 1526 onwards, therefore, the historical statehood narrative also has to trace a history of political activism aimed at unifying the disparate lands of the medieval kingdom.

One of the most significant legacies bequeathed by the Habsburgs was the military frontier (Vojna Krajina), which was established on the border of the Habsburg and Ottoman Empires. Groups residing in the Vojna Krajina came under the direct authority of the Habsburg Emperor, creating further divisions 
in the Croatian polity. ${ }^{64}$ In return for military service in the Habsburg armies, the frontiersmen were exempt feudal dues and were loaned land by the Emperor. ${ }^{65}$ They were also awarded special religious exemptions, which were important for the accommodation of Orthodox Serbs and Vlachs migrating from the Ottoman Empire. ${ }^{66}$ In return for concessions and exemptions, the Emperor secured a cheap source of manpower with which to garrison the frontier. ${ }^{67}$ As a result of numerous wars with the Ottomans and the constant cross-frontier raiding, the Vojna Krajina became depopulated and hence more vulnerable to Ottoman incursion. The Habsburgs therefore encouraged the settlement of Orthodox Christian Serbs and Vlachs who were migrating from Ottoman-held territory ${ }^{68}$ The historical statehood narrative recalls that the Vojna Krajina galvanised Croatian national sentiment by providing a focus for political mobilisation. From its establishment until its reincorporation with socalled Civil Croatia in the nineteenth century, the Sabor constantly demanded that Zagreb be allowed to exert its authority over Vojna Krajina and effectively reunite the lands of today's northern Croatia. ${ }^{69}$

\section{The national awakening}

The campaign for uniting the different entities that had comprised the medieval kingdom lay at the heart of the national movement when Croatian national identity started to be more clearly articulated during the nineteenth and early twentieth centuries. The growth and development of Risorgimento-type nationalism in Croatia has often been attributed to the brief period of occupation by Napoleonic France at the beginning of the nineteenth century. However, the precise nature of the French legacy and its relationship to the historical statehood narrative is contested. On one hand, many nationalists attribute the birth of the national movement to the ideas of self-determination articulated by the French. On the other hand, communist historians argue that all forms of imperialism must be pernicious. Moreover, some Croatian nationalist historians agreed with the communists because they wanted to emphasise the positive links between Croatia and Austria as a way of challenging panSlavism and denying the significance of subjugation to the French, which could potentially challenge the idea of continuous statehood..$^{70}$

During the Napoleonic War, the Croatian army fought on the side of the Habsburg Empire against the French. ${ }^{71}$ Under the 1797 Treaty of Campoformio, most of the territory comprising present-day Croatia and Slovenia (including Dubrovnik) was transferred to French control. Napoleon decided to resurrect the ancient name of Illyria as a geographical and administrative term for his new acquisitions, a change that was apparently welcomed by Italian-educated Croatian intellectuals, who understood the liberal and potentially revolutionary implications of the name. ${ }^{72}$ In 1810 Marshal Marmont arrived in the province with the task of incorporating it into the French Empire. Although short-lived, 
Marmont's reforms were extensive. He introduced the Code Napoleon, which formed the basis of French law and provided for the abolition of serfdom, equality before the law, and an independent judiciary. He also attempted to introduce free trade, something that had been suppressed by previous imperial overlords. Most crucial for the development of Croatian nationalism, however, were the linguistic and educational reforms. A quasi-universal school system was introduced, which began teaching the Štokavian dialect of the Croatian language. This dialect also became the official administrative language of Croatia for the first time since the medieval kingdom. Marmont encouraged writing and printing in the Croatian language and allowed Vincenze Dandolo to produce the first ever periodical in the Croatian language - Kraglski Dalmatin. ${ }^{73}$

The place of Marmont's reforms in the historical narrative is disputed. One view is that the French occupation was of immense significance to the development of Croatian national identity. Napoleon integrated most of the Croatian lands (including Croatia, Dalmatia, Istria, Vojna Krajina and Dubrovnik, but omitting Zagreb) into the Illyrian province, making them a single entity for the first time since the venerated Triune Kingdom. The abolition of serfdom broke down the legal distinction between nobles and peasants and created the possibility for the development of a larger urban middle class. Moreover, by promoting the use of the Croatian language and the idea of universal compulsory education, Marmont's reforms facilitated the development of a national literature. ${ }^{74}$ As Kann argued, 'probably the Illyrian peoples perceived the basis of their brief prosperity not so much in the enlightened spirit of the reforms introduced by a foreign conqueror as in the fact that under the French regime they had been united for the first time in many centuries..$^{75}$

However, many nationalist writers opposed the idea that the French occupation may have contributed to national developments seeing in it instead a further challenge to the idea of continuous statehood. As Guldescu put it, 'it is altogether erroneous to hold that the Croatians ever welcomed or were satisfied with the change in sovereignty.$^{76} \mathrm{He}$ pointed to the bitterness caused by the abolition of the Dubrovnik Republic and the fact that Croatian troops fought for Austria rather than France as indicative of the absence of co-operation between the French and Croats that is implied in the other accounts. He also pointed out that the French regime increased taxes, causing further resentment among Croatian peasants. It is also likely that the illiterate peasants would not have understood Marmont's enlightened reforms and that the significance of the union of Dalmatia with Croatia would have been lost on them. ${ }^{77}$ After Napoleon's defeat at Waterloo, the Illyrian provinces were restored to the Habsburg Empire and Marmont's reforms were swiftly revoked. Following the Napoleonic Wars, Croatian intellectuals and politicians came to regard Austria as a potential ally against the threat of Magyarisation produced by the development of nationalism in Hungary. According to many contemporaries, closer union with Austria would allow a reassertion of Croatia's historic stateright that had been eroded by the Magyars. 
The primary threat to the development of an independent Croatian political identity within the Habsburg Empire is widely understood to have been the emergence of the Magyar nationalist leader, Kossuth. This new nationalist movement attempted to establish a single centralised Kingdom of Hungary stretching from the Carpathian Mountains in the north to the Dalmatian Adriatic Sea in the south. ${ }^{78}$ The idea of such a kingdom threatened to eradicate any semblance of Croatian political autonomy. Between the end of the Napoleonic Wars and the liberal revolutions of 1848, the Magyar nationalists embarked on a Magyarisation programme in Croatia. For example, they insisted that the Magyar language be taught in schools and used for all official purposes. Dalmatia was spared this process, however, because under the terms of the 1815 Versailles Treaty it came under the direct authority of Austria.

By the mid-nineteenth century, therefore, the historical statehood narrative confronts two challenges: the battle against the Magyar nationalists and the fact that the Croatian lands were divided. These two factors make it potentially very difficult to trace a continual line of statehood, prompting historians to look instead for evidence of Croatian political actors fighting against Magyar nationalism in the cause of Croatian unification. These circumstances helped produce one of the heroes of the Croatian historical narrative, Ban Josip Jelačić. It is perhaps odd that one of the heroes of Croatian nationalism should be a servant of Vienna, but this veneration only serves to emphasise the political and historical rather than ethnic base of abstract conceptions of Croatian national identity. Indeed, one of the first acts of the new Croatian government at the beginning of the 1990s was to restore a statue of Jelačić that had been removed by the communists. Ironically, that statue - a symbol of Croatia's national history given pride of place in Zagreb's central square - was first built and erected by Austria not Croatia.

Jelačić gained 'tragic hero' status for his successful campaign that defended the Vienna Habsburgs against Kossuth's nationalist Hungarian army. He hoped that through his loyalty to the Empire he would persuade the Habsburgs to unite the Croatian lands in a sovereign and autonomous state that would share the same status as Hungary. ${ }^{79}$ In 1848 Magyar nationalists revolted against the Austrians, aiming to create an exclusively Hungarian empire. Jelačić led the Croatian army in a successful war against the Magyars. Indeed, it was the Croatian army that prevented the Magyars taking Vienna before the Russians intervened and suppressed Kossuth and his followers. Despite his loyalty to Vienna, Jelačić's efforts failed to secure greater autonomy for Croatia. A cruel but accurate joke that was frequently recited opined that following the events of 1848-49 Croatia received as a reward from the Habsburgs what the Magyars received as a punishment. ${ }^{80}$ Communist historiography branded Jelačić a reactionary, but he was venerated by nationalists, despite the fact that his loyalty ultimately lay in Vienna rather than Zagreb.

Twenty subsequent years of constitutional bickering between the Sabor and the Hungarians produced the Nagodba (compromise), which tried to define 
Croatia's status and in doing so marked an important justificatory landmark for the historical statehood narrative. The Nagodba recognised that Croatia was 'a political nation possessing a special territory of its own' ${ }^{81}$ It also provided for provincial autonomy under the Sabor in Zagreb and established Croatian as the official language for all autonomous and common affairs pertaining to the Croatian territory. Finally, it provided for the eventual return of the Vojna Krajina to the civil administration of Croatia. ${ }^{82}$ As with most aspects of the historical narrative there is strong debate about the meaning of the Nagodba. In particular, nationalist historians point out that it recognised Croatia's historic right to statehood, while others have pointed to the great disappointment felt by Croatian politicians and intellectuals. ${ }^{83}$ Grievances centred on the constraints placed upon the autonomy of the Sabor. All important decisions regarding the Croatian economy and transportation were to be taken in Budapest, and the head of the autonomous government, the Ban, would be appointed by the Hungarians and would still be answerable to the Hungarian Diet rather than to the Sabor. Dalmatia remained under Austrian authority, despite pledges to unite it into the Triune Kingdom, and Hungary annexed parts of Slavonia. ${ }^{84}$ On the one hand, the Nagodba offered succour for proponents of the historical statehood narrative by acknowledging that Croatia was separate from Hungary. On the other hand, it re-emphasised the separation of the lands of the medieval kingdom, which made the historic statehood claim more problematic.

\section{Competing national ideologies}

Although the historic statehood thesis claims that Croatian national identity is based on the idea of shared history and statehood, the first nationalist movements that developed in the second half of the nineteenth century put many different ideas forward about what Croatian national identity was and where it came from. These competing ideologies had two important consequences for the historical statehood narrative. First, for the first time different national ideologies were developed that made use of competing interpretations of the historical statehood narrative. Second, these different national ideologies produced different political ideologies in the twentieth century. One of the tasks that confronted Tuðman in his attempt to enforce a particular understanding of national identity in the 1990s was to unite these different national ideologies. We will see how he tried to do this in the following chapter, but it is worth noting here that these different understandings of national identity ultimately proved impossible to unite, although they all made use of the frames provided by the historical statehood narrative.

The first and most prominent of the nineteenth-century national movements was the Illyrian movement. In the early and mid-nineteenth century many members of the Croatian intelligentsia believed that the best way to combat Magyarisation was to embark on a counter-Magyar national programme. 
This programme, which also articulated a linguistic alternative to Hungarian and Latin, began in the 1830s and 1840s and became known as the Illyrian movement. ${ }^{85}$ Initially, Illyrianism was a cultural movement inspired by the poetry of Ljudevit Gaj and Janko Drasković, but after 1841 it became the dominant political and national ideology among intellectuals and the bourgeois strata of Croatian society under the tutelage of Bishop Josip Strossmayer.

Ljudevit Gaj was a student of law at the universities of Graz and Budapest, where he was influenced by the Slovak nationalist Jan Safaryk. Gaj proposed the introduction of diacritic signs for the Latin alphabet as a way of spelling Croatian words. Underlying Gaj's work was an attempt to establish a common identity for all Croatian peoples through the creation of a common literary language and the claim that those who shared this linguistic identity had the right to determine the nation's future. ${ }^{86}$ Gaj reintroduced the term 'Illyria' in order to transcend the national differences between Croats, Serbs and Slovenes, and he argued that the Southern Slavs were direct descendants of the Illyrians. ${ }^{87}$ Gaj argued that the establishment of a common literary language was essential for the development of an Illyrian national consciousness and he attempted to bring together the three main dialects used by the Southern Slavs - Štokavian, Cakavian and Kajkavian - into a single literary language. ${ }^{88}$ For Gaj, it was only through the establishment and dissemination of such a language that Croatia could withstand the onslaught of Magyarisation. In 1827 he wrote that 'in an illiterate land such as ours, it seems important, yes, most necessary to bring all powers to bear upon awakening an effective and noble cultural patriotism ... The story of our fatherland has already taught me how much it deserves to be lifted out of the miserable Magyar darkness. ${ }^{89}$ For Gaj, Illyrianism was about establishing a Southern Slavic or Croatian high culture through which a national identity could be established as a means of challenging Magyar nationalism. He established a Croatian newspaper written in the Stokavian dialect that was closest to the Serbian language, and encouraged the establishment of reading rooms and political clubs. ${ }^{90}$ Gaj was also involved in the founding of Matica Hrvatska, a patriotic society that published and disseminated books in the Croatian language. ${ }^{91}$

Illyrianism later became more political than cultural and eventually gave birth to a political party. As it did so, its proponents began to make use of the historical statehood narrative. These initiatives were led by Bishop Josip Strossmayer, who is often accredited with being the 'first Yugoslav'. ${ }^{92}$ Strossmayer believed that the term 'Illyrian' was an artificial and foreign word, so he replaced it with 'Yugoslav' (South Slav). ${ }^{93} \mathrm{He}$ was disillusioned with both the Habsburgs and the Hungarians and sought an alternative path by building upon Gaj's attempts to establish a common literary language for all Southern Slavs. Strossmayer established the Yugoslav Academy of Arts and Sciences in Zagreb, which he hoped would give the new nation its own intellectual life to parallel the Magyar, Austrian and Italian intellectual establishments. Strossmayer also took the issue of Serb-Croat unity a stage further by working on a 
programme to transcend the differences between Orthodox and Catholic Christianity, which he believed hampered possibilities for a Serb-Croat union. ${ }^{94}$ His interest in reconciliation with the Orthodox churches was not reciprocated in Serbia, where he was regarded as a cunning spokesperson for Rome. ${ }^{95}$ This recalcitrance caused Strossmayer's eventual disillusionment with the Yugoslav project. ${ }^{96}$

The cause of Serb-Croat unity articulated by these Croatian intellectuals was never received well in Serbia. According to Ivo Banac, the principal reason for this was that Strossmayer refused to rule out Croatia's claims to historic statehood. Although the Illyrianists sought to unite the Southern Slav people, they still maintained the principle of Croatia's right to statehood. ${ }^{97}$ This was unacceptable to the Serbs, who envisaged a possible Yugoslav state as more akin to a 'Greater Serbia' than the loose federation envisaged by the Illyrianists. Nevertheless, at the beginning of the 1840s the movement became a fully fledged political party whose programme consisted of the establishment of Štokavian as a literary language for the southern Slavs, the unification of all Croatian lands within the Habsburg Monarchy, and the attainment of closer ties with Bosnia-Hercegovina, Serbia and Bulgaria. ${ }^{98}$

Although Illyrianism is the most widely discussed nineteenth-century national ideology, it was by no means the only one. According to Mirjana Gross, it is possible to identify five different national ideologies that developed in Croatia during this period. ${ }^{99}$ These she described as: Illyrism (Illyrianism), Yugoslavism, the Party of Right, the peasant movement and social democrats. Gross outlines a typology in which Illyrianism, Yugoslavism and the social democrats stand juxtaposed to the others, who articulated exclusive Croatian nationalism. Within this typology, though, there is a clear distinction between the Illyrianism of Strossmayer and Gaj, which envisaged some form of loose union between the Southern Slavs including the Bulgarians, and the unitary Yugoslavism of Trumbić and Supilo that informed the work of the Yugoslav Committee in London during the First World War. ${ }^{100}$ Outside the intelligentsia, the Party of Right and the Croatian Peasants' Party (HSS) were the most popular. Interestingly, although these ideologies spanned the political spectrum, they all made use of particular interpretations of the historical statehood narrative.

The Party of Right (HSP) was founded in the 1860s by Ante Starčević and Eugen Kvaternik. The old Croatian constitution provided the foundation for their political programme and they believed that the only power that the Croats should deal was that of the King of Croatia-Slavonia and Dalmatia - the Emperor of Austria. ${ }^{101}$ Starčević was one of the leading critics of the Nagodba, which he believed negated Croatia's right to statehood. The cornerstone of Starčević's ideology was the maintenance of this perceived historical right to statehood. ${ }^{102} \mathrm{He}$ demanded the creation of a 'great Croatia', encompassing Croatia, Slavonia, Istria, Dalmatia, Dubrovnik, and Bosnia and Hercegovina. ${ }^{103}$ More troubling was the fact that Starčević downplayed the religious differences between Croats and Serbs by arguing that the Serbs of Bosnia and Vojna Krajina 
were merely Orthodox Croats, who, like the Bosnian Muslims, would voluntarily acknowledge their tie to the historic Croatian nation once it was shown to them. ${ }^{104}$ The national ideology of the Party of Right was thus firmly rooted in the idea of the Croats as a 'political people' who had a historic right to statehood enjoyed since the ninth century. This 'primary acquisition' established 'the eternal and natural Croat right to ownership of the land' ${ }^{105}$

The only political movement to command substantial support outside the economic and intellectual elite was Stjepan Radićs Croatian Peasant Party, which competed its first election in $1905 .{ }^{106}$ Radić was convinced that the future belonged to the Croatian peasantry and espoused both the doctrine of Croatia's state-right and the continuation of the Habsburg Monarchy, albeit a reformed Monarchy that would be both democratic and federal. ${ }^{107}$ Under Radićs programme, the Kingdom of Croatia would be a federal state in which the Croats, Slovenes and Serbs who lived in the Habsburg Empire would organise their own affairs, leaving those who lived outside the Monarchy to organise themselves into a separate Yugoslav state if they so desired..$^{108}$ On culture and language, the Radić favoured the establishment of a folk-peasant culture that would transcend the traditional divisions of nation and religion, allowing Serbs and Muslims to participate in the movement. However, it proved problematic to equate peasant republicanism, Croatian exclusivism (keeping Croatia out of Yugoslavia) and a commitment to the Monarchy, prompting Radić regularly to contradict himself. ${ }^{109}$ Hence, it was only after the formation of the Kingdom of Serbs, Croats and Slovenes that the Peasants' Party (HSS) became the leading party in Croatia and Radić's vision assumed some degree of consistency.

The range of national ideologies in Croatia in the nineteenth and early twentieth centuries therefore included Yugoslavism, Croatian exclusivism and Austrianism. Importantly, despite the variety of political programmes put forward by these ideologies, they all shared three common traits. First, they all demanded the unification of Croatia, Dalmatia, Slavonia and Istria. Second, they were democratic to some extent and wanted to see the Sabor exert more control over Croatia. Finally, they called for a constitution that acknowledged Croatia's historic right to statehood. ${ }^{110}$ Each of these ideas draws upon the historical statehood narrative, suggesting that it provided a powerful frame for Croatian political rhetoric and activism. With the dissolution of the Habsburg Empire at the end of the First World War, the Croatian elite was presented with a threefold dilemma about the direction it could take. The options were: remain inside Austria, declare national unification and independence in a revived Triune Kingdom, or enter into a union with the Serbs and Slovenes. Most Croatian historians argue that while the majority of Croats favoured either the first or second option, the elite (which consisted of a high proportion of Serbs) opted for the third without consulting the will of the people or the Sabor. Thus the events of 1918 should be ranked alongside 1102 and 1526 as a defining and controversial moment in the historical statehood narrative. 


\section{Croatia and Yugoslavia}

These different ideologies remained after Croatia entered the Kingdom of Serbs, Croats and Slovenes. The question now though was not one of how Croatia should relate to Hungary but how it should relate to Serbia. The first forty years of the twentieth century also added two new national ideologies that made the task of unifying them in the 1990s all the more problematic. These were the powerful and diametrically opposed ideologies of fascism and communism. Despite these developments, the main debates about Croatian national identity in the early twentieth century, and the core claims put forward by the growing number of nationalists, were still more concerned with the veracity of the historic statehood narrative than they were with the supposed ethnic heritage of Croats.

While the First World War raged, with Croats fighting with the AustroHungarians against the Serbs, the Yugoslavists set up the Yugoslav Committee in London under the leadership of Supilo and Trumbić. ${ }^{111}$ The Yugoslav Committee advocated a federal Yugoslav state and lobbied for the creation of a unified Yugoslavia based on the principle of self-determination later enunciated by Woodrow Wilson in his 'fourteen points'. The reality of the first Yugoslav state, known as the Kingdom of Serbs, Croats and Slovenes, was somewhat different. In place of federalism was monarchical centralism and in place of selfdetermination was the rule of law of the Kingdom of Serbia. The Kingdom of Serbs, Croats and Slovenes was to be ruled by the Serb Royal family, under King Aleksander. ${ }^{112}$

There is some evidence that Croats welcomed the Yugoslav idea, despite the fact that it constituted a major rupture to the historic statehood narrative. The Habsburg commander in Bosnia and Hercegovina, Ekmečić, noted that although loyalty to the Empire remained strong in Slavonia until the end of the war, the war's ending brought a slight majority in favour of Yugoslavism in the rest of the country. Furthermore, Ekmečić noted that the level of support for the Yugoslav idea was greater in Dalmatia. ${ }^{113}$ Leroy King, an American dispatched to Zagreb to gather intelligence at the end of the war, reached a similar conclusion. In 1919 King wrote that, '[t]he vast majority of the Croatians are strongly supporting a united Jugoslavia [sic]'. ${ }^{114}$ Croatian historians tended to dispute this point fiercely. They argued that there may have been a brief period after the collapse of the Habsburg Empire where the Serb alternative was preferable to a feared Italian conquest. However, they argued that by 1919, when it was apparent that the Yugoslav state would be a Serb-dominated entity, there was a great deal of opposition in Croatia to the now mutated idea of Yugoslavia. Stephen Gazi pointed to Stjepan Radić's opposition as indicative of a general Croatian hostility towards the Yugoslav project. ${ }^{115}$ Radić declared that Croats who supported the Yugoslav Committee were acting like 'drunken geese in the fog' ${ }^{116}$ Croatian opposition tended to draw an unhappy comparison between the new Yugoslavism and Croatia's position in the Habsburg Empire. 
Typical of this was a statement by Miroslav Krleža, one of Croatia's most prominent writers, who asserted that:

As a nation, within the framework of the 1918 unification, the Croats have lost all the attributes of their statehood. These attributes, to be sure, were falsely decorative, but nevertheless, in spite of centuries, they were preserved as relics and symbols of a certain liberty, which, through a negation of every democratic liberty, was not entirely devoid of political reality: the crown as the mark of sovereignty, banners, arms, army, autonomy. From any current Croat conservative aspect, it cannot be proved to the Croats that in Austria they did not live in the Kingdom of Croatia, and that they are today not a satrapy, ruled by the most anonymous chiefs of government. ${ }^{117}$

The argument follows that the new state was accepted by Croats made weary by a long war that had left many impoverished. While there was no great mass support for the Yugoslav idea, there was initially a resigned acceptance of the new state, exemplified by the position taken by the Catholic Church, which viewed the state as 'an irreversible development'. ${ }^{118}$ However, because the new kingdom did not reaffirm Croatia's historic statehood, it constituted a major problem for the historic statehood narrative. Croatian nationalist writers therefore tended to make three points to challenge the legitimacy of the new kingdom. First, they argued that most Croats did not support the creation of the new state. Because Croatia was not a democracy and opinion polls were not much used there is no way of testing this claim and Yugoslavist counter-claims.

Second, many writers argued that Yugoslavists in Croatia and abroad were hoodwinked by the Serbs. They argued that this ought to render the kingdom illegitimate. Prior to and during the war, R. W. Seton-Watson had been a leading proponent of the Yugoslav idea. He worked closely with the Yugoslav Committee in London and had secured a considerable amount of access to the British government for them. In a letter to Herbert Fisher in 1918, SetonWatson argued that the Croats were becoming more pro-Yugoslav: '[As] indication of feeling in Croatia, I may mention that a secret meeting was held last year in Fiume [Rijeka] at which a number of priests, Capuchins and Franciscans, representatives of clerical parties and even of the Archbishop of Zagreb himself were present, and means were found to convey to the Jugoslav [sic] committee their approval of its propaganda'. ${ }^{119}$ This positive view changed after the Vidovdan (St Vitus day - the day of ratification) Constitution was promulgated in 1921. In 1921 Seton-Watson lamented that 'the situation in Jugoslavia $[$ sic] reduces me to despair', and stated that, 'I have no confidence in the new constitution, with its absurd centralism'. ${ }^{120}$ According to Seton-Watson the situation continued to deteriorate. In 1923 he wrote that 'the political situation ... is utterly deplorable, for all the most honest and progressive politicians in the country are pare terre and all the scoundrels oben and there is the most complete disorientation and dissatisfaction everywhere'. ${ }^{121}$ The disenchantment of the Croat Yugoslavists is perhaps best captured by Ante Trumbić, one 
of the leading Yugoslavists who, in conversation with the French writer Henri Pozzi, declared that 'the dream of a unified south Slavdom has withered and died in less than sixteen years, and now its corruption stinks across the length and breadth of Europe'. ${ }^{122}$

Third, many writers argued that Croatia's entry into the new kingdom had no legal basis because neither the Croatian Sabor nor the Croatian people gave their consent. The decision to join the kingdom was taken by a special committee rather than by the Sabor as a whole, in sharp distinction to the decisions in 1102 and 1526 it was contended. This line of argument points to the fact that when given the chance to vote, Croats tended to support Croatian nationalist parties rather than pan-Yugoslav parties. In the first elections in 1920, Radićs Croatian Peasants' Party (HSS) swept the board in Croatia, winning nearly 40 per cent of the vote and becoming Croatia's largest party. ${ }^{123}$ Radić changed his manifesto and advocated a federation in which Serbia and Croatia would have a relationship similar to the relationship between Austria and Hungary in the old empire. However, under the new constitution, Belgrade had the right to appoint regional governors and the state apparatus was placed firmly in the hands of the centre. Radić and the HSS responded by withdrawing from the Škupstina (the parliament in Belgrade) and declaring their determination to oppose the constitution.

Between 1920 and the end of the decade, disputes between the kingdom's different nations increased. Croatian historians argued that the illegitimate kingdom was ruining the Croatian economy by restricting its trade with Central Europe and forcing it to pay substantial dues to Belgrade. Typical of this argument is Gazi's calculation that Croatia paid 686 million Dinars more in tax than Serbia did, despite Serbia having a population more than double Croatia's. ${ }^{124}$ The situation worsened still further when, on 14 June 1928, the newspaper Jedinstvo (Unity), which was close to the government, published an open invitation for Radić to be assassinated. ${ }^{125}$ Six days later, Puniša Račić, a Četnik war veteran ${ }^{126}$ crossed the house of the Škupstina and fired a revolver at the group of HSS representatives. Pavle Radić, Stjepan's nephew, was killed instantly and although Stjepan appeared to be recovering from his wounds, he too died on 8 August. ${ }^{127}$ The Archbishop of Zagreb tolled the great bell of Zagreb cathedral - a dignity only normally accorded to deceased bishops - and throughout Croatia the bells of parish churches tolled in mourning. ${ }^{128}$ Radić was buried in Zagreb on 12 August at a funeral that was described as 'resembling more the funeral of a great monarch than of a one-time republican politician', as more than 100,000 people took part in the funeral procession through Zagreb. ${ }^{129}$ The extent of the crisis in Croatia and the threat of civil war prompted the King to summon the new leader of the HSS, Vladko Maček, for talks on the possibility of a peaceful dissolution of the kingdom. ${ }^{130}$

At the beginning of 1929 King Aleksander dissolved the parliament and decreed that he would rule his kingdom directly. Radićs successor, Vladko Maček, initially welcomed this because it signalled the end of the hated Vidovdan 
Constitution, which he had described as a 'badly buttoned vest'. ${ }^{131}$ Maček hoped that the King would accord greater autonomy to Croatia by releasing it from rule by Serbian politicians and he optimistically noted that 'there is no longer a constitution, only a king and a people'. ${ }^{132}$ However, the King banned all nonYugoslav political parties (including the HSS), imprisoned their leaders, changed the name of the kingdom to 'The Kingdom of Yugoslavia', introduced harsh censorship of the press and tolerated no political dissent. ${ }^{133}$ Most critically for the historical statehood narrative, he abolished the former constituent entities (Croatia, Slovenia, Bosnia and Hercegovina, and Serbia) and introduced nine regional Banovine, which bore the names of rivers. The name Croatia was removed from official use for the first time since it was established in the medieval Triune Kingdom. To rub salt into the wounds, Croatia and Dalmatia were again split into two entities. The political situation in Croatia became so bad that it attracted external attention. In 1931 Albert Einstein and Heinrich Mann called upon the rest of Europe to defend the Croats, stating 'all countries are duty bound to shield the small, peaceful and civilised nation of Croatia'. ${ }^{134}$

The political crisis was worsened by the collapse of the European banking system, which impacted heavily on Zagreb because of its close links with Austria and was exacerbated by a series of bad harvests. This prompted a trend towards extremism in Croatian politics and the emergence of both fascist and communist political movements. There was also a marked increase in terrorist activity. The Yugoslav League of Communists (KPJ), the Internal Macedonian Revolutionary Organisation (VMRO) and the infamous fascist Ustaša, though small in size, participated in many acts of bombing and assassination in the 1930s. In 1934, while on a visit to France, King Aleksander was assassinated by a member of VMRO who was aided by the Ustaša. ${ }^{135}$ Fascist Italy was incriminated in the murder, resulting in a Yugoslav-Italian pact in 1937 in which Mussolini agreed to stop supporting the fascist Ustaša (Mussolini had provided it with arms and training camps in Italy) and intern Ante Pavelić, its leader.

By the second half of the 1930s, the HSS had become even more popular under Maček's leadership. Not only did the peasant movement attract the support of its traditional supporters, it also secured a substantial level of support among the Croatian bourgeoisie and intelligentsia. Indeed, by 193540 per cent of the party's representatives were from the middle class. Despite these changes, the party retained its traditional focus as Maček was keen to ensure that the HSS remained a parliamentary movement. It also strongly resisted the Ustaša's violent methods and its membership dwarfed that of the fascists. ${ }^{136}$

The increasing level of support for the HSS and the increasing instability of the international arena prompted the government to reach an agreement with the Croats. In 1939 Maček and the Belgrade government reached a sporazum (agreement) that reorganised the Yugoslav state, awarding substantial autonomy to Croatia. The sporazum created an autonomous Croatian Banovina, which encompassed about 30 per cent of the entire kingdom - including Croatia, Slavonia, Dalmatia, Hercegovina and parts of northeastern Bosnia (Brčko). 
Croatia was to have a separate Ban and the Sabor was to be reinstated. Only foreign policy, transportation and other pan-kingdom areas of administration were to remain in Belgrade and the Sabor would decide everything else. ${ }^{137}$ Some historians believed that the sporazum had the potential to solve the Serb-Croat conflict that had dogged the kingdom since its creation. However, the Axis invasion of Yugoslavia in 1941 meant that its potential was never fulfilled. ${ }^{138}$ Nevertheless, for Croatian historians intent on tracing a continuous line of statehood, the sporazum reasserted the existence of the Croatian state through the reincarnation of the institutions of the Ban and Sabor.

\section{The age of extremes}

Having concluded the sporazum, Prince Paul tried to secure Yugoslavia against the perceived threat from Italy by finally succumbing to German demands for Yugoslavia to join the Axis tripartite pact. ${ }^{139}$ Within Serbia, news of Yugoslavia's agreement with Germany was greeted with mass demonstrations, which provided the signal for those in the army who were opposed to the sporazum to launch a coup against the King. ${ }^{140}$ Winston Churchill commented that Yugoslavia had found its soul and delighted at the creation of a new front against the Germans. ${ }^{141}$ The new front lasted ten days and cost only 166 German troops. ${ }^{142}$ The German occupation ushered in four years of bloodletting in Yugoslavia and drove Croats into one of two extremist movements: the fascist Ustaša led by Ante Pavelić and the communist Partisans led by Tito.

The self-proclaimed leader of the Ustaša,${ }^{143}$ Ante Pavelić, was a Hercegovinian Croat, the son of a building contractor. He believed that he was following in the footsteps of Ante Starčević and the Party of Rights movement. He was the first prominent Croatian nationalist to base his nationalism on ethnic grounds, despite the fact that earlier and contemporary ethnic genealogists had failed to outline a convincing ethnic heritage. Pavelić viewed the Jews and Serbs who had settled in Croatia as agents of Magyarisation who should not have the same rights as Croats. Having studied law at Zagreb University, he was elected municipal councillor in Zagreb. He represented Zagreb in the Škupstina, before founding the Ustaša. Pavelić organised the illegal Ustaša on military lines and advocated an armed struggle for Croatian independence. Until 1937, he received a great deal of support from Mussolini, whose territorial designs on the Dalmatian coast were well known. The Ustaša was based in Italy, from where it launched terrorist attacks in Yugoslavia. However, after the 1937 YugoslavItalian treaty, it was imprisoned in Italy until 1941 when Mussolini installed it as the Croatian government. It is important to note that the Ustaša did not have popular support. Avakumović argues that this was because of its association with Italy and because the HSS was more representative of Croatian opinion. ${ }^{144}$ However, this did not prevent it unleashing an era of terror upon Croatia and Bosnia and Hercegovina. 
Shortly after the German invasion, the infamous Nezavisna Država Hrvatska (Independent State of Croatia - NDH) led by Ante Pavelić was created. The historical controversy of this period is of vital importance to understanding competing claims about the historical statehood narrative in the 1990s. Until the advent of 'Franjoism' in the 1990s (outlined in the following chapter), the narrative tended to avoid the subject of the Ustaša regime altogether. Its partial reinclusion in the 1990s as a legitimate expression of Croatian statehood was a major source of contention between Croats in the 1990s. ${ }^{145}$

The new fascist government issued its first decrees on 17 April 1941. The death penalty was introduced for a range of offences such as abortion. On 26 April the use of Cyrillic (the alphabet used by Serbs) was forbidden and in June and October a whole range of anti-Semitic legislation was passed. The systematic murder of Jews, Serbs, Gypsies and Croatian opponents began immediately. In October 1941 Vladko Maček was arrested and sent to Jasenovac, where a brick factory had been converted into a Croatian Auschwitz. ${ }^{146}$ Maček recalled that:

The camp had previously been a brick-yard and was situated on the embankment of the Sava river. In the middle of the camp stood a two-storey house, originally erected for the offices of the enterprise ... The screams and wails of despair and extreme suffering, the tortured outcries of the victims, broken by intermittent shooting, accompanied all my waking hours and followed me into sleep at night. ${ }^{147}$

Vladimir Dedijer compiled a chilling collection of witness accounts of Ustaša atrocities committed by the NDH regime. One such act was committed at Karitska Jama Gorge, in Bosnia and Hercegovina, which was described by a survivor, Milija Bjelica:

They tried to kill us not with wooden hammers, but shot us by using only two bullets for each group of three. The henchmen placed us in threes, tied back to back at the edge of the gorge ... The shots, which came from close up, were fired into the temples of the ones standing at the sides, and hit the back of the head of the one facing the gorge. Apparently the henchmen did not check to see whether all three were mortally wounded each time, but instead just immediately threw them into the twenty meter deep gorge, causing anyone who was not dead to perish there in torment. ${ }^{148}$

There are many similar, and many more horrific, testimonies of Ustaša atrocities. Under the policy declared by Education Minister, Mile Budak, of deporting a third [of Serbs], converting a third [to Catholicism] and killing a third, the Ustaša terror reached such proportions that some Italian and German fascists complained about the barbarity of the Croats. An observer in the German army noted that, 'even among the Croatians nobody can feel safe in this land anymore ... The Croatian revolution is by far the harshest and most brutal of all the different revolutions that I have been through at more or less close hand since 1918'. ${ }^{149}$

One of the greatest controversies of the Ustaša period was the apparently eager compliance of the Catholic Church. Serbian and communist historians 
tend to argue that the papal regime actively supported the massacre of Orthodox Serbs and provide evidence of priests and Franciscans who actively participated in atrocities. Furthermore, Dedijer argued that Archbishop of Zagreb, Alojzije Stepinac - beatified by the Pope in 1998 - actively supported the Pavelić regime. ${ }^{150}$ The role of Stepinac has become a focal point for different nationalist interpretations of what happened in Croatia between 1941 and 1945. Contrary to the argument that Stepinac actively supported the genocide, many Croatian writers believe that although he supported the cause of Croatian statehood he abhorred the Pavelić regime and helped many people to escape from it.

After the German invasion and the creation of the NDH, Stepinac spoke approvingly of the new regime and in particular of Croatian independence, and met with Pavelić and his deputy, Kvaternik, on 16 April $1941 .{ }^{151}$ However, the wholesale deportation of Jews and Serbs seriously worried him. In a letter to the poglavnik (the leader of the Ustaša) he wrote that:

I am convinced that these things have been happening without your knowledge and that others may not dare to tell you about them ... I hear from many sides that there are instances of inhumane and brutal treatment of non-Aryans during the deportations and at the camps, and even worse that neither old people, children or the sick are spared ... the measures which have been undertaken would have their full effect if they were carried out in a more humane and considerate way, seeing in human beings the image of god. ${ }^{152}$

Stepinac also forwarded to Pavelić a communiqué he had received from Bishop Mišić of Mostar. Mišić's report read:

A reign of terror has come to pass ... men are captured like animals. They are slaughtered, murdered; living men are thrown off cliffs ... From Mostar and Čapljina a train took six carloads of mothers, young girls and children ten years old to the station at Surmanci ... they were led up the mountains and mothers together with their children were thrown alive off precipices. ${ }^{153}$

Marcus Tanner argued that what prevented Stepinac from openly opposing Pavelić was not sympathy for the regime but political naivety. Tanner recorded an instance where Stepinac enquired whether or not the leader knew of the reports of the killing of Serbs. When he was told that, of course, Pavelić knew everything, Stepinac broke down in tears. ${ }^{154}$ However, Stepinac never made a public statement disavowing the NDH, even when he was put on trial by Tito in $1946 .{ }^{155}$

The omission of the Ustaša period from the historical statehood narrative meant that not only have Croatian historians failed to disavow the NDH until recently (and then only partially), they have also - with the exception of Franjo Tuðman (see Chapter 4) - failed to reveal the extent of the opposition to the $\mathrm{NDH}$ within Croatia. Because the imprisoned Maček clung on to the pacifist tradition of the HSS, most Croatian opponents of the Ustaša turned to the communist Partisans under Tito's leadership. By the end of 1943, Croats made up over 30 per cent of a total number of Partisans that exceeded 100,000, meaning that there were more Croatian Partisans than there were Ustaša militia. ${ }^{156}$ 
Controversies about the Second World War are vitally important to the historical statehood narrative. Discussion was severely restricted during the years of Tito's Yugoslavia (1945-1980), and when discussion was permitted this period of history became a highly politicised area of contention. Numbers and culpability play a big part in these debates. It is estimated that the Ustaša killed around 300,000 Serbs, most of Croatia's 36,000 Jews and a large portion of the 200,000 Croats that were killed in the war. These figures were highly contested in the 1990s and these political contests were related directly to different interpretations of the historical statehood narrative.

There are three key areas of debate about the Second World War. The first is the question of whether the $\mathrm{NDH}$ was a legitimate expression of Croatian statehood. It is very difficult to say that it was, while denying that expressions of Croatian national identity have fascist connotations. On the other hand, denying its legitimacy brings the claim of continual statehood into question. Second, there is the question of the level of support enjoyed by the Ustaša. Was Ustaša fascism supported by Croats and their social institutions (the Catholic Church) or was there widespread resistance? Third, did the Ustaša commit genocide against the Serbs or was the killing more indiscriminate and a consequence of the on-going civil war? Of these, the first two questions in particular posed problems in the 1990s when Tuðman tried to unite the different strands of national thinking into a single national movement, as we will see in the following chapter.

\section{Tito's Yugoslavia}

As part of their attempt to eradicate completely all forms of political opposition, the communists hosted a series of show trials similar to those held during the Stalinist purges. The most famous of these show trials were of the Četnik leader, Draža Mihailović, and the Archbishop of Zagreb, Alojzije Stepinac. Mihailović was found guilty of collaboration and was shot in 1946. In the same year, Stepinac was put on trial for colluding with the Ustaša and was sentenced to 16 years in prison. ${ }^{157}$ Throughout Croatia and Serbia anyone suspected of having colluded with either the Četniks or the Ustaša was either imprisoned or executed.

In the first twenty years after the end of the Second World War there was very little by way of a Croatian national movement and no attempt to legitimise the new socialist Yugoslav state in terms of the historical statehood thesis (by arguing that socialist Yugoslavia's federal constitution recognised the sovereignty of the Croatian nation). Instead, the narrative tells us that Croatia had communism imposed on it and finally lost its statehood. Rather than pointing towards continuity, the narrative focuses instead on national opposition to the second Yugoslavia. Maček fled abroad in fear of the communists and never returned to Croatia. ${ }^{158}$ Although Stepinac was released from prison in 1951, he was held in a form of house arrest well away from Zagreb until his death in 
$1960 .{ }^{159}$ By the mid-1960s, however, Croats within the League of Communists began to reassess Croatia's position and began to raise the issue of the need to assert Croatia's historic right to statehood within the Yugoslav federation. In the mid-1960s Croatian communists adopted a strategy of opposing everything that was centralist and Yugoslav. ${ }^{160}$ The main targets for these new Croatian communist leaders were the constitution - which they deemed to be too centralist; democratic centralism - which they believed contradicted the idea of republican democracy; old Partisan communists; and the continuing federal control over foreign currency - the majority of which was earned by Croatia. ${ }^{161}$ These new leaders began to pose as defenders of the Croatian nation against the exploitation of the centre (Belgrade), which was accused of draining off Croatian currency to fund inefficient programmes in the less-developed republics and provinces (southern Serbia, Kosovo, Macedonia and Montenegro). From the mid-1960s onwards, all economic and political issues within the Croatian League of Communists became subsumed within the national question. ${ }^{162}$

The revival of Croatian national consciousness began among intellectuals, with the resuscitation of concern for the cultural questions posed by earlier nationalists. They began questioning the 1954 Novi Sad language agreement, which established a common Serbo-Croatian and equally Croato-Serbian language. ${ }^{163}$ Their opposition took the form of a declaration in 1967, which argued that the Croatian language had been downgraded into a local dialect. ${ }^{164}$ They demanded that Croatian be established as Croatia's official and be used in schools and the state media. ${ }^{165}$ An important centre for this new movement was the reinvigorated Matica Hrvatska. Matica Hrvatska focused on the perceived denigration of Croatian culture. Its journal, Kritika, caricatured Belgrade as a metaphor for the ruthless, bourgeois, backward Serbs who were oppressing the more advanced Croats. Intellectuals argued that this was the only reason why Croatia was not as prosperous as the small nations of Western Europe. ${ }^{166}$ In April 1971 this movement was joined by fascist groups that operated among the large Croatia gasterbeiter (overseas workers) who murdered the Yugoslav ambassador in Stockholm and held a celebration in Munich to celebrate the thirtieth anniversary of the foundation of the $\mathrm{NDH} .{ }^{167}$

The federal government adopted a dual response to the problem of increasing Croatian intransigence. Matica Hrvatska was closed down and many nationalists, including Franjo Tuðman, were jailed. Liberal and nationally minded leaders of the Croatian League of Communists, such as Miko Tripalo and Savko Dabčević-Kučar, were removed from office and replaced by loyal ultra-conservatives such as Stipe Šuvar. Every rank of the party was subjected to the purge and thousands of Croats were expelled, increasing the already disproportionately high relative number of Serbs within the party. The purge, which came to be known as the 'Croatian Spring', crushed every form of political opposition in Croatia. ${ }^{168}$ Hence, for the next twenty years, until the first democratic elections of 1990, Croatia was known as the 'silent republic' because its communist leadership avoided all forms of confrontation at a time in which the 
Slovene party in particular was becoming increasingly liberal, progressive, and nationally minded. ${ }^{169}$

Following Tito's death in 1980, the last ten years of Croatia's membership of Yugoslavia were years of economic and political collapse. More than at any other time in the historical statehood narrative, the discourse was intimately linked with events in Serbia, the rise of Slobodan Milošević in Serbia, the Kosovo question, and anti-Croat propaganda emanating from Belgrade. ${ }^{170}$ In the mid1980s the economy worsened as the national debt increased. In 1986 the Serbian Academy of Arts and Sciences (SANU) released its now infamous Memorandum, which insisted that the Serb nation was threatened by an anti-Serb conspiracy that was being hatched in Croatia, and concluded ominously that '[b] ut for the period of the existence of the NDH, Serbs in Croatia have never been as threatened as they are now'. ${ }^{171}$ In 1987 Slobodan Milošević came to the fore in a visit to the Serbs in Kosovo. He told the Kosovan Serbs that 'no one has the right to beat the [Serb] people' and used nationalist rhetoric to seize control of the Serbian presidency.

On 19 November of the same year, Milošević implied that war would break out if the Serbs in Kosovo did not get their own way. ${ }^{172}$ By the late 1980s, the Serbian nationalist propaganda machine had turned its attentions towards 600,000 Serbs living in Croatia. Belgrade television showed mistreated Serbs and decaying Serb villages that had been neglected by the hateful Croats, and demonstrations in the stronghold of Knin, in the former Vojna Krajina (known today as the Lika region), became regular occurrences.

It was 1989 before the Croats began to respond to this upsurge in Serb nationalism. In February 1989, Franjo Tuðman and a group of others involved in the 'Croatian Spring', illegally formed the Hrvatska Demokratska Zajednica (Croatian Democratic Union - HDZ), the first non-communist or fascist party in Croatia since the demise of the HSS and incarceration of Maček in 1941. The 'Croatian silence' came to an abrupt end in December 1989 when the Croatian League of Communists elected the liberal reformist, Ivica Račan, as party leader. Račan immediately shifted Croatian policy towards Belgrade, and fell in behind the Slovene leadership in their decision to walk out of the party congress of 1990. This decision was made in response to Serb gerrymandering with the federal budget, in which 1.8 billion Dinar (around $\$ 1$ billion) was removed from the Federal Bank reserves and given to the Republic of Serbia. The Croatian League of Communists, again following Slovenia, changed its name (to the DSP) and called Croatia's first free elections.

To guarantee victory, the revamped League of Communists established an electoral system that would ensure that it secured a higher proportion of parliamentary seats than it secured share of the vote. The plan backfired. Most of the 600,000 Serbs in Croatia voted for Serbian parties rather than the reformed communists, who had become more Croatian in outlook. By being all things to all Croats, Tuðman and the HDZ secured large amounts of funding for their campaign. ${ }^{173}$ This funding came largely from Croatian émigrés, organised by the 
future Defence Minister Gojko Šušak. Moreover, there were many other new parties in Croatia, which split the votes that the (former) communists were hoping to secure. The electoral system also conspired against the party, and allowed the HDZ to secure nearly 70 per cent of parliamentary seats with only 40 per cent of the vote. ${ }^{174}$ Franjo Tuðman was elected President of Croatia by the HDZ-dominated Sabor. ${ }^{175}$

Although Tuðman never explicitly called for Croatian independence during the campaign, he made it clear that a future Croatia would function on an independent basis within 'a radically reorganised Yugoslavia'. ${ }^{176}$ It was only after the outbreak of fighting and the intervention of the JNA (Yugoslav People's Army) coupled with the continuing intransigence of the Serb leadership, that a snap referendum on independence was held, after the Serbs blocked the rotation of the federal presidency, which would have put the Croat (and future Croatian President), Stipe Mesić (legally if not practically) at the head of the JNA. Croatian Serbs boycotted the referendum, which produced an overwhelming vote in favour of independence. ${ }^{177}$ On 30 May 1991 Croatia declared its independence from Yugoslavia but had to wait until the beginning of 1992 for recognition. ${ }^{178}$ By that time, the city of Vukovar had been demolished by the Serbs and Dubrovnik had been badly damaged.

\section{Abstract narratives of Croatian identity}

Conceptions of Croatian national identity in the 1990s were framed by the historical statehood narrative with its claim that Croatia has enjoyed continuous statehood since the time of the medieval kingdom. According to Croatian politicians and intellectuals, 'people' become 'Croats' through a perceived shared history of statehood. Unlike the Serbian nation, which found continuity in Orthodox Christianity, Croatian national identity is founded upon statehood and was perpetuated by the continuity of that statehood. ${ }^{179}$ Most writers who articulate the historical narrative claim that the two Yugoslavias were illegitimate because the Sabor had not freely chosen to enter into the union, unlike - it is claimed - the unions with Hungary in 1102 and Austria in 1526. The historical statehood narrative insists that the Croats entered these unions to protect themselves against the Ottomans but that throughout this period Croatia retained a degree of freedom of action that it did not enjoy in the two Yugoslavias. Furthermore, it stresses the separate development of Croats and Serbs, showing that prior to 1918 the two nations had little connection other than a similar language.

As an account of the abstract ways that Croatian national identity is framed, the narrative of historical statehood offers a set of referent points that constitutes and constrains the way that political entrepreneurs at the second level can invoke resonant claims about national identity in order to legitimise particular political programmes. The task now is to address the question of how 
these abstract accounts of Croatian national identity became resonant in the 1990s. Although the historical statehood narrative helps to distinguish Croats from other nationalities and situates them in an albeit contentious continuous political community since the tenth century, it tells us little about the salience or meaning of that identity. While we can accept that the years 1102, 1526 and 1918 provide vital signposts in the thesis of continuous statehood and that it is a shared belief in this legacy of statehood that distinguishes the Croatian nation from others by providing an abstract consciousness, there is nothing in the historical narrative to explain how and why these dates should be so powerful in constituting the modern political consciousness of people calling themselves Croats. The next chapter considers four sets of accounts that attempted to make these abstract ideas of Croatian national identity resonant in the everyday lives of Croats in the 1990s, either by mobilising people behind one or other political programme or by criticising those programmes and the forms of consciousness they tried to construct.

\section{Notes}

1 Address of the President of the Republic of Croatia on the state of the nation at the joint session of both chambers of the Croatian National Parliament, 27 January 1998. Translation issued by Croatian Information Centre, Zagreb, 28 January 1998.

2 Opening statement in Chapter 1 of the Constitution of the Republic of Croatia, 1991. Translated by the Croatian Information Centre, Zagreb.

3 I. Banac The National Question in Yugoslavia: Origins, History, Politics (London: Cornell University Press, 1984), p. 49.

4 See I. Banac, 'Historiography of the countries of Eastern Europe: Yugoslavia', American Historical Review, 97:4 (1992).

5 M. Gross, Počeci moderne Hrvatske. Neoapsolutizam u civilnoj Hrvatskoj i Slavoniji 18501860 (Zagreb: Globus, 1985).

6 See G. W. Hoffman, The Balkans in Transition (London: Van Nostrand Co., 1963), p. 26, and R. L. Wolff, The Balkans in Our Times (Cambridge Mass: Harvard University Press, 1956), p. 31.

7 Banac, The National Question in Yugoslavia, p. 9.

8 M. Tanner, Croatia: A Nation Forged in War (London: Yale University Press, 1997), p. 7.

9 S. Gazi, A History of Croatia (New York: Philosophical Library, 1973), pp. 1 and 12.

10 H. M. V. Emperley, History of Serbia (London: G. Bell and Sons, 1919), p. 12.

11 R. Portal, The Slavs (London: Weidenfield and Nicolson, 1969), p. 1.

12 Portal, The Slavs, p. 14.

13 S. Vladovich, Croatia: The Making of a Nation (Oklahoma: Vladovich Publishing, 1995), p. 4.

14 This is a widely accepted version of events. See, for example, I. Babić, 'Military History', in F. Eterovich and C. Spalatin (eds), Croatia: Land, People, Culture, volume 1 (Toronto: University of Toronto Press, 1970), p. 131; S. Guldescu, 'Political history to 1526', in Eterovich and Spalatin (eds), Croatia: Land, People, Culture, p. 82; and Tanner, Croatia: A Nation Forged in War, p. 9.

15 Guldescu, 'Political history to 1526 ', p. 82.

16 Portal, The Slavs, p. 14. The Carpathian location of the Slavs and their common movement is also accepted by Muriel Heppell. M. Heppell and F. B. Singleton, Yugoslavia 
(London: Ernest Benn Ltd., 1961), p. 31. For a detailed exploration of the movements of the Slavs in this period see J. Fine, The Early Medieval Balkans: A Critical Survey from the Sixth to the Twelfth Century (Ann Arbor: University of Michigan Press, 1983).

17 F. Schevill, A History of the Balkans From the Earliest Times to the Present Day (New York: Dorset Press, 1991), p. 73.

18 Tanner, Croatia: A Nation Forged in War, p. 2.

19 Gazi, A History of Croatia, p. 11.

20 Tanner, Croatia: A Nation Forged in War, p. 3.

21 Gazi, A History of Croatia, p. 11.

22 Hoffman, The Balkans in Transition, p. 26.

23 See Guldescu, 'Political history to 1526', p. 77.

24 Gazi, A History of Croatia, p. 12.

25 G. MacDonald, Area Handbook for Yugoslavia (Washington DC: US Government Printing, 1st edition, 1973), p. 26.

26 V. Markotić, 'Archaeology', in Eterovich and Spalatin (eds), Croatia: Land, People, Culture, p. 64.

27 See the Introduction of A. J. Bellamy, Kosovo and International Society (London: Palgrave-Macmillan, 2002).

28 Constitution of the Republic of Croatia, Chapter 1.

29 H. C. Darby, 'Croatia', in H. C. Darby and R. W. Seton-Watson, A Short History of Yugoslavia from Early Times to 1966 (Cambridge: Cambridge University Press, 1968), p. 23.

30 See MacDonald, Area Handbook for Yugoslavia, p. 29, and J. R. Lampe, Yugoslavia as History: Twice There Was a Country (Cambridge: Cambridge University Press, 1996), p. 14.

31 Tanner, Croatia: A Nation Forged in War, p. 9.

32 See Darby, 'Croatia', p. 24.

33 Recorded by Guldescu, 'Political history to 1526', p. 94.

34 S. Vladovich, Croatia: The Making of a Nation, p. 10.

35 See J. Borošak-Marijanović, Croatian Flags Through the Centuries (Zagreb: Hrvatski Povijesni Muzej, 1996); A. J. Bellamy, 'Reclaiming the Croatian Flag', Rethinking History, 3:3 (1999); S. Granić, 'The Croatian Coat of arms: historical emblem or controversial symbol?', Journal of Croatian Studies, 24-5 (1993-94).

36 I am grateful to the Croatian National Mint for this information.

37 The controversy over the use of Croatian symbols, which later became associated with fascism, will be discussed at greater length in the following chapters. On the origin of the symbols see Guldescu, 'Political history to 1526', p. 96.

38 Guldescu, 'Political History to 1526', pp. 98-100 and Vladovich, Croatia: The Making of a Nation, p. 12.

39 Guldescu, 'Political history to 1526', p. 103.

40 Guldescu, 'Political history to 1526', p. 103.

41 E. M. Despalatović, Ljudevit Gaj and the Illyrian Movement (London: Moulton and Co., 1975), p. 10.

42 Banac, The National Question in Yugoslavia, p. 12.

43 F. R. Preveden, A History of the Croatian People, volume 2 (New York: Philosophical Library, 1962), p. 87.

44 S. Guldescu, History of Medieval Croatia to 1526 (The Hague: Moulton and Co., 1964), p. 306.

45 Guldescu, History of Medieval Croatia, p. 316.

46 Gazi, A History of Croatia, p. 54.

47 B. M. Janković, The Balkans in International Relations (London: Macmillan, 1988), p. 29.

48 Janković, The Balkans, p. 29.

49 The Magyar version of events is widely expressed in the literature. Roger Portal notes that the Hungarians 'conquered' Croatia, Portal, The Slavs, p. 96; As do, Anon, Jugoslavia: 
Vol. II: History, Peoples, Administration (London: Naval Intelligence Division Handbook Series, 1944), p. 16, and Hoffman, The Balkans in Transition, p. 44.

50 Guldescu, 'Political history to 1526', p. 104.

51 Guldescu, History of Medieval Croatia, p. 180.

52 Croatian Sabor Pragmatic Sanction of 11 March 1712. Cited by Gazi, A History of Croatia, p. 114.

53 Constitution of the Republic of Croatia.

54 C. A. Maccartney, Hungary and her Successors (Oxford: Oxford University Press, 1937), p. 357.

55 Gazi, A History of Croatia, p. 93.

56 S. Guldescu, 'Croatian political history 1526-1918', in F. Eterovich and C. Spalatin, Croatia: Land, People, Culture, volume 2 (Toronto: University of Toronto Press, 1970), p. 5.

57 Gazi, A History of Croatia, p. 94.

58 Sabor declaration cited by Gazi, A History of Croatia, p. 95.

59 Guldescu, 'Croatian political history 1526-1918', p. 7.

60 Heppell and Singleton, Yugoslavia, p. 93.

61 See Anon, Jugoslavia: Vol. II, p. 20.

62 See Z. Zlatar, Between the Double Eagle and the Crescent (New York: East European Monographs No. 348, 1992).

63 Lampe, Yugoslavia as History, pp. 27 and 29.

64 Lampe, Yugoslavia as History, p. 29.

65 Guldescu, 'Political history 1526-1918', p. 16. For an extended account of the establishment of the military frontier and the politics surrounding its existence see G. E. Rothenberg, The Military Border in Croatia: A Study of an Imperial Institution (London: University of Chicago Press, 1966).

66 Gazi, A History of Croatia, p. 105.

67 B. Jelavich, History of the Balkans: Eighteenth and Nineteenth Centuries, volume 1 (Cambridge: Cambridge University Press, 1983), p. 156.

68 Guldescu, 'Croatian political history 1526-1918', p. 9, and C. Bracewell, The Uskoks of Senj: Piracy, Banditry and Holy War in the Sixteenth-Century Adriatic (London: Cornell University Press, 1992), pp. 29-30.

69 MacDonald, Area Handbook for Yugoslavia, p. 30.

70 See Tanner, Croatia: A Nation Forged in War, p. 72.

71 Gazi, A History of Croatia, p. 124.

72 Gazi, A History of Croatia, p. 133.

73 See Gazi, A History of Croatia, pp. 125-6, and Lampe, Yugoslavia as History, p. 42.

74 Arguments taken from Anon, Jugoslavia: Vol. II, pp. 22-4.

75 R. A. Kann, The Multinational Empire: Nationalism and National Reform in the Habsburg Monarchy 1848-1918 (New York: Columbia University Press, 1950), p. 244.

76 Guldescu, 'Croatian political history 1526-1918', p. 37.

77 See Tanner, Croatia: A Nation Forged in War, p. 72.

78 For an exhaustive account of Kossuth's political ambitions see O. Zarek, Kossuth (London: Selwyn and Blount, 1942). A more general account of the rise of Magyar nationalism in the early nineteenth century is offered by C. A. Maccartney, Hungary: A Short History (Edinburgh: Edinburgh University Press, 1962).

79 Guldescu, 'Croatian political history 1526-1918', p. 41, and Anon, Jugoslavia: Vol. II, p. 26.

80 Tanner, Croatia: A Nation Forged in War, p. 91.

81 Cited by Anon, Jugoslavia: Vol. II, p. 27.

82 For details of the Nagodba see Gazi, A History of Croatia, pp. 150-5; Guldescu, 'Croatian political history 1526-1918', pp. 46-50; and I. Omrčanin, Diplomatic and Political History of Croatia (Philadelphia: Dorrance, 1972).

83 See Guldescu, 'Croatian political history 1526-1918', pp. 46-50. 
84 Gazi, A History of Croatia, pp. 166-7.

85 Banac, The National Question in Yugoslavia, p. 75.

86 F. Trogrančić, 'Literature 1400-1835', in F. Eterovich and C. Spalatin (eds), Croatia: Land, People, Culture, volume 1 (Toronto: University of Toronto Press), p. 238.

87 Lampe, Yugoslavia as History, p. 42.

88 Lampe, Yugoslavia as History, p. 44. The linguistic impact of the Illyrian movement is exhaustively outlined in G. Thomas, The Impact of the Illyrian Movement on the Croatian Lexicon (Munich: O. Sagner, 1988).

89 Cited and translated by Despalatović, Ljudevit Gaj, p. 41.

90 Portal, The Slavs, p. 365.

91 Gazi, A History of Croatia, p. 137.

92 R. W. Seton-Watson, The Southern Slav Question (London: G. Bell and Sons, 1911), p. 128.

93 Seton-Watson, The Southern Slav Question, p. 160.

94 Seton-Watson, The Southern Slav Question, p. 160.

95 Tanner, Croatia: A Nation Forged in War, p. 101.

96 Josip Strossmayer, cited by Tanner, Croatia: A Nation Forged in War, p. 101.

97 Banac, The National Question in Yugoslavia, p. 90.

98 See Guldescu, 'Croatian political history 1526-1918', p. 39, and Gazi, A History of Croatia, p. 140.

99 M. Gross, 'Croatian national-integrational ideologies from the end of Illyrism to the creation of Yugoslavia', Austrian History Yearbook, 15-16 (1979), 3.

100 Gross, 'Croatian national-integrational ideologies', 3-15.

101 Guldescu, 'Croatian political history 1526-1918', p. 44.

102 M. Biondich, 'Stjepan Radić, Yugoslavism, and the Habsburg Monarchy', Austrian History Yearbook, 27 (1996), 113.

103 Biondich, 'Stjepan Radić', 45.

104 Lampe, Yugoslavia as History, p. 60.

105 Banac, The National Question in Yugoslavia, p. 86.

106 For a detailed analysis of the life and political career of Stjepan Radić see S. Gazi, 'Stjepan Radić: his life and political activities 1871-1928', Journal of Croatian Studies, 14-15 (1973-74). On the origins of the HSS see S. Gazi, 'Beginning of the Croatian Peasant Party: A historico-political study', Journal of Croatian Studies, 3-4 (1962-63).

107 Banac, The National Question in Yugoslavia, p. 104.

108 Banac, The National Question in Yugoslavia, p. 104.

109 For a more detailed insight into the pre-First World War policies of the Radić brothers see Biondich, 'Stjepan Radić', 118-31.

110 See Gazi, A History of Croatia, p. 192.

111 On the role of Croatia in the First World War see I. Omrčanin, Military History of Croatia (Philadelphia: Dorrance, 1984).

112 For detailed accounts of the negotiations that led to the formation of the Kingdom of Serbs, Croats and Slovenes see D. R. Živojinović, America, Italy and the Birth of Yugoslavia: 1917-1919 (London: Columbia University Press, 1979), and I. J. Lederer, Yugoslavia at the Paris Peace Conference (London: Yale University Press, 1963).

113 See V. Ekmečić, 'Serbian War Aims', in D. Djordjević, The First Yugoslavia: The Search for a Viable Political System (Santa Barbara: ABC -Clio, 1980), pp. 25-6.

114 See Tanner, Croatia: A Nation Forged in War, p. 120.

115 Gazi, 'Beginning of the Croatian Peasant Party', 324.

116 Tanner, Croatia: A Nation Forged in War, p. 278.

117 Miroslav Krleža, 1933, cited by Banac, The National Question in Yugoslavia, p. 260.

118 Banac, The National Question in Yugoslavia, p. 419. There were, however, outbreaks of violence against the new state. See I. Banac, 'Emperor Karl has become a Comitadji: the Croatian disturbances of 1918', Slavonic and East European Review, 70:2 (1992). 
119 R. W. Seton-Watson - letter to Herbert Fisher, 9 October 1918. H. Seton-Watson (ed.), R. W. Seton-Watson and the Yugoslavs: Correspondence 1906-1941, volume 1 (London: British Academy, 1976), p. 28.

120 R. W. Seton-Watson - letter to Milan Čurčin, 2 December 1921. Hugh Seton-Watson (ed.), R.W. Seton-Watson and the Yugoslavs: Correspondence 1906-1941, volume 2 (London: British Academy, 1976), p. 97.

121 R. W. Seton-Watson - letter to May Seton-Watson, 15 April 1923. Seton-Watson (ed.), R. W. Seton-Watson and the Yugoslavs, volume 2, p. 102.

122 Ante Trumbić in conversation with Henri Pozzi. H. Pozzi, The Black Hand Over Europe, reprint of the 1935 edition (Zagreb: Croatian Information Centre, 1994), p. 24.

123 A full breakdown of the 1920 election result is provided by Lampe, Yugoslavia as History, p. 121. The HSS won 50 seats, with the second largest party in Croatia - the Democrats winning 19 seats.

124 Gazi, A History of Croatia, p. 304. Gazi does not reveal the source of his calculation, saying only that by 1928 'it was known that ...'.

125 See the quote in Tanner, Croatia: A Nation Forged in War, p. 123

126 The Cetnici were Serb royalist fighters in the First World War.

127 The story of the Škupstina murders is found in the same form in all the works on Yugoslav history of this period. The best accounts of the actual event can be found in Lampe, Yugoslavia as History, p. 158; R. W. Seton-Watson and R. G. D. Laffan, 'Yugoslavia between the wars', in H. C. Darby and R. W. Seton-Watson, A Short History of Yugoslavia from Early Times to 1966 (Cambridge: Cambridge University Press, 1968), p. 174; and Gazi, A History of Croatia, p. 305. On the background and consequences of the event see Tanner, Croatia: A Nation Forged in War, pp. 124-9.

128 Tanner, Croatia: A Nation Forged in War, p. 124. Tanner cites R. Horvat on this point.

129 Tanner, Croatia: A Nation Forged in War, p. 124.

130 L. J. Cohen, Broken Bonds: Yugoslavia's Disintegration and Balkan Politics in Transition, 2nd edition (Oxford: Westview, 1995), p. 16.

131 Lampe, Yugoslavia as History, p. 161.

132 Maček is cited by Seton-Watson and Laffan, 'Yugoslavia between the wars', p. 174.

133 See Seton-Watson and Laffan, 'Yugoslavia between the wars', p. 174 and Gazi, A History of Croatia, p. 309.

134 This statement is widely reported. This citation is taken from Vladovich, Croatia: The Making of a Nation, p. 44.

135 See Lampe, Yugoslavia as History, p. 170-3; M. Almond, Europe's Backyard War: The War in the Balkans (London: Mandarin, 1994), p. 125; and S. Graham, Alexander of Yugoslavia: The Story of the King who was Murdered in Marseilles (New Haven: Yale University Press, 1939).

136 I. Avakumović, 'Yugoslavia's fascist movements', in P. F. Sugar (ed.), Native Fascism in the Successor States: 1918-1945 (Santa Barbara: ABC-Clio, 1971), p. 140. Also see S. Trifković, 'The first Yugoslavia and origins of Croatian separatism', East European Quarterly, 26:3 (1992).

137 See Tanner, Croatia: A Nation Forged in War, pp. 132-5; Lampe, Yugoslavia as History, pp. 191-2; Seton-Watson and Laffan, 'Yugoslavia between the wars', p. 197; and Gazi, A History of Croatia, pp. 326-7.

138 G. F. Vrbanić, The Failure to Save the First Yugoslavia: The Serbo-Croatian Sporazum of 1939 (Chicago: Ziral, 1991), p. 37.

139 H. Seton-Watson, Eastern Europe Between the Wars 1918-1941 (Cambridge: Cambridge University Press, 1946), p. 152.

140 S. Trifković, 'Yugoslavia in crisis: Europe and the Croat question, 1939-41', European History Quarterly, 23 (1993), 547-50.

141 W. R. Roberts, Tito, Mihailović and the Allies 1941-45 (New Jersey: Rugters University Press, 1973), pp. 11-14. 
142 M. C. Wheeler, Britain and the War for Yugoslavia 1940-43 (New York, Columbia University Press, 1980) p. 59. Also see M. C. Wheeler, 'White eagles and white guards: British perceptions of anti-communist insurgency in Yugoslavia in 1945', Slavonic and East European Review, 66 (1998).

143 Ustaša means uprising - an Ustaši is one who participates in an uprising.

144 The background on Pavelić and discussion of the lack of support for fascism is taken from Avakumović, 'Yugoslavia's Fascist Movements', pp. 139-41.

145 Writers within the Croatian diaspora have been particularly keen to rehabilitate the NDH. For example, see S. Hefer, Croatian Struggle for Freedom and Statehood (Buenos Aires: Croatian Information Service, 1956).

146 Jasenovac was undoubtedly the most renowned death camp in the NDH, which continues to inspire controversy today. See L. Boban, 'Jasenovac and the manipulation of history', East European Politics and Societies, 4:3 (1990); L. Boban, 'Still more balance on Jasenovac and the manipulation of history', East European Politics and Societies, 6:4 (1992); M. Bulajić, Tudjman's 'Jasenovac Myth' Ustaša Crimes of Genocide (Belgrade: Ministry of Information of the Republic of Serbia, 1992); and R. M. Hayden, 'Balancing discussion of Jasenovac and the manipulation of history', East European Politics and Societies, 6:4 (1992).

147 J. Steinberg, 'Types of genocide? Croatians, Serbs and Jews, 1941-5', in D. Cesarani (ed.), The Final Solution: Origins and Implementation (London: Routledge, 1994), p. 176.

148 Testimony of Milija Bjelica in V. Dedijer, The Yugoslav Auschwitz and the Vatican: The Croatian Massacre of the Serbs During World War II (New York: Prometheus Books, 1992), p. 160.

149 Steinberg, 'Types of genocide?', p. 181.

150 Dedijer, The Yugoslav Auschwitz and the Vatican.

151 Lampe, Yugoslavia as History, p. 205.

152 Cited by S. Alexander, The Triple Myth: A life of Archbishop Alojzije Stepinac (New York: East European Monographs, 1987), pp. 71-2.

153 Alexander, The Triple Myth, p. 80.

154 Tanner, Croatia: A Nation Forged in War, pp. 155-6.

155 Lampe, Yugoslavia as History, p. 218.

156 It is estimated by John Lampe that the entire NDH regime - including officers and bureaucratic officials - never exceeded 50,000 people, of which less than 30,000 were part of the militia - according to Mark Almond. See Lampe, Yugoslavia as History, p. 219 and Almond, Europe's Backyard War, p. 137.

157 A thorough narrative of the trial, which makes extensive use of primary documentation is provided by S. Alexander, Church and State in Yugoslavia Since 1945 (Cambridge: Cambridge University Press, 1979), Chapter 3.

158 Tanner, Croatia: A Nation Forged in War, p. 174.

159 Tanner, Croatia: A Nation Forged in War, p. 186.

160 S. K. Pavlowitch, The Improbable Survivor: Yugoslavia and its Problems 1918-1988 (Columbus: Ohio State University Press, 1989), p. 25.

161 D. Rusinow, The Yugoslav Experiment: 1948-74 (London: C. Hurst and Co. for the Royal Institute of International Affairs), pp. 248-9.

162 Rusinow, The Yugoslav Experiment, pp. 248-9.

163 The language question will be addressed in greater detail in Chapter 6. Details on the 1954 Novi Sad agreement and the 1967 declaration are taken from B. Franolić, Language Policy in Yugoslavia With Special Reference to Croatian (Paris: Nouvelles Editions Latines, 1988). It is worthy of note that this edition was presented to the Hugh Owen Library at the University of Wales, Aberystwyth by the Croatian Peasants' Party (HSS). Also see A. N. Luk, 'The linguistic aspect of ethnic conflict in Yugoslavia', in P. Akhavan and R. Howse (eds), Yugoslavia: The Former and Future (Washington DC: The Brookings Institute, 1995). 
164 Franolić, Language Policy in Yugoslavia, p. 16.

165 Franolić, Language Policy in Yugoslavia, p. 16.

166 Rusinow, The Yugoslav Experiment, p. 250.

167 Rusinow, The Yugoslav Experiment, p. 250.

168 On the 'Croatian Spring' see A. Cuvalo, The Croatian National Movement 1966-72 (New York: Columbia University Press, 1990); A. Cuvalo, 'Croatian nationalism and the Croatian national movement (1966-1972) in Anglo-American publications - a critical assessment', Journal of Croatian Studies, 30 (1989); and M. Veselica, The Croatian National Question: Yugoslavia's Achilles' Heel (London: United Publishers, 1981).

169 See Tanner, Croatia: A Nation Forged in War, pp. 196-202.

170 There was an immense amount of literature equating all forms of Croatian national expression with Ustaša fascism and inciting fear and hatred among the Croatian Serbs. See, for example, S. Kljakić, A Conspiracy of Silence: Genocide in the NDH and the Concentration Camp Jasenovac (Belgrade: Ministry of Information of the Republic of Serbia, 1991); R. Petrović, The Extermination of the Serbs on the Territory of Croatia (Belgrade: Ministry of Information of the Republic of Serbia, 1991); E. Paris, Genocide in Satellite Croatia: A Record of Racial and Religious Persecutions and Massacres (Melbourne: Srpska Misao, 1981); and Serbian Academy of Arts and Sciences (SANU), Some Basic Facts About the Position of Serbian People in Croatia (Belgrade: SANU, 1991).

171 SANU, Some Basic Facts, p. 1.

172 Tanner, Croatia: A Nation Forged in War, p. 216.

173 See V. V. Godina, 'The outbreak of nationalism on former Yugoslav territory: a historical perspective on the problem of supranational identity', Nations and Nationalism, 4:3 (1998).

174 For a detailed breakdown of the 1990 elections see I. Siber (ed.), The 1990/93 Sabor Elections in Croatia: Analysis, Documents and Data (Berlin: Edition Sigma, 1997).

175 See I. Grdešić, '1990 Elections in Croatia', Croatian Political Sciences Review, 1:1 (1992), pp. 97-9.

176 C. Cviić, 'Croatia', in D. A. Dyker and I. Vejvoda (eds), Yugoslavia and After: A Study in Fragmentation, Despair and Rebirth (London: Longman, 1996), p. 206.

17793.2 per cent voted in favour of a 'sovereign and independent Croatia'. Vladovich, Croatia: The Making of a Nation, p. 214. On the Serb problem, see B. Kovačević, 'A view on the proposals for the solution of the Serb question in Croatia', Gaudeamus, 4 (1991).

178 The intricacies of the dissolution of Yugoslavia have been well documented elsewhere. On the specificities on the referendum, declaration and eventual recognition see L. J. Cohen, 'The disintegration of Yugoslavia', Current History, 91:568 (1992); and A. James, 'The UN in Croatia: An exercise in futility', World Today, 49:5 (1993). For views on the recognition debate see N. S. Dokić, 'The international community and the case of Croatia and Slovenia', International Spectator, 27:4 (1992); J. Gow, Legitimacy and the Military: The Yugoslav Crisis (London: Pinter, 1992); and C. C. Hodge, 'Botching the Balkans: Germany and the recognition of Slovenia and Croatia', Ethics and International Affairs, 12 (1998).

179 See D. N. Šuljak, Croatia's Struggle for Independence: A Documentary History (Arcadia California: Croatian Information Service, 1977) and S. M. Vujica, Croatia's Struggle for Independence (New York: Croatian National Council in Exile, 1965). 